Supporting information:

\title{
Langmuir-Blodgett Patterning of Phospholipid Microstripes: Effect of the Second Component
}

Xiaodong Chen, Nan Lu, Hui Zhang, Michael Hirtz, Lixin Wu, Harald Fuchs, and Lifeng Chi

\section{The synthesis of 1,2-di(2,4-octadecadienoyl)-sn-glycero-3-phosphocholine (DOEPC)}

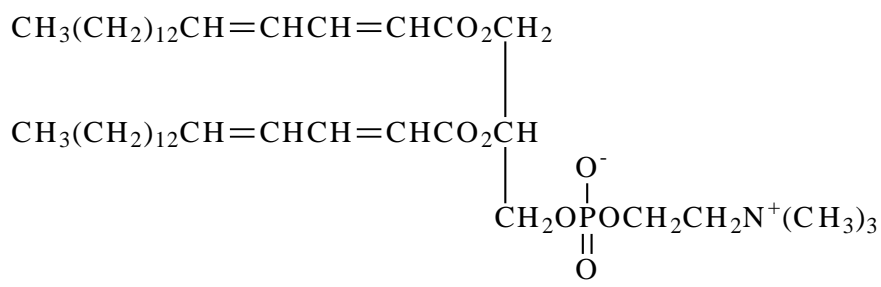

\section{Tetradecanal}
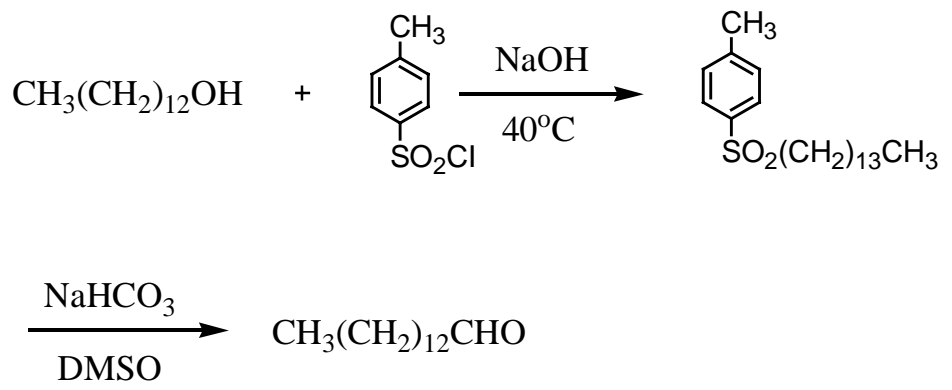

1-Tetradecanol (6.4 g, $0.03 \mathrm{~mol})$ and toluene-4-sulfonyl chloride were added in flask. After that, $15 \mathrm{ml}$ of $40 \% \mathrm{NaOH}$ was added dropwise. The mixture was stirred at $40{ }^{\circ} \mathrm{C}$ for $5 \mathrm{~h}$. Then, the reaction mixture was added in $100 \mathrm{ml}$ water. The product was extracted with $\mathrm{Et}_{2} \mathrm{O}$. The combined extracts were dried $\left(\mathrm{Na}_{2} \mathrm{SO}_{4}\right)$ and evaporated. The solid was chromatographed on silica gel eluted with ligroin/ $/ \mathrm{Et}_{2} \mathrm{O}$ gradient, yield 9.39 g.

$\mathrm{NaHCO}_{3}(14.7 \mathrm{~g})$ was added in $85 \mathrm{ml} \mathrm{DMSO}$ and then heated to $150^{\circ} \mathrm{C}$. The above product was dissolved in $10 \mathrm{ml}$ DMSO and was added also in reaction flask, kept up for $5 \mathrm{~min}$. The mixture was cooled to room temperature, added $500 \mathrm{~g}$ ice, then was extracted with $\mathrm{Et}_{2} \mathrm{O}$ three times. The organic layer was washed with water, dried 
over anhydrous $\mathrm{MgSO}_{4}$ and evaporated. The solid was chromatographed on silica gel eluted with ligroin/dichloromethane: yield $3.88 \mathrm{~g}$.

\section{Octadecadienoic Acid}

$$
\begin{aligned}
& \mathrm{CH}_{3}\left(\mathrm{CH}_{2}\right)_{12} \mathrm{CHO}+\quad \stackrel{\mathrm{O}}{\mathrm{O}} \\
& \underset{273 \mathrm{~K}}{\mathrm{NaH}} \longrightarrow \mathrm{CH}_{3}\left(\mathrm{CH}_{2}\right)_{12} \mathrm{CH}=\mathrm{CHCH}=\mathrm{CO}_{2} \mathrm{C}_{2} \mathrm{H}_{5} \\
& \stackrel{\mathrm{KOH}}{\longrightarrow} \quad \mathrm{CH}_{3}\left(\mathrm{CH}_{2}\right)_{12} \mathrm{CH}=\mathrm{CHCH}=\mathrm{CHCO}_{2} \mathrm{H}
\end{aligned}
$$

A suspension of $2.0 \mathrm{~g} \mathrm{(50} \mathrm{mmol} \mathrm{)} \mathrm{of} 60 \%$ sodium hydride mineral oil dispersion in $100 \mathrm{ml}$ of dry THF was stirred at $0^{\circ} \mathrm{C}$ when $12.5 \mathrm{~g}(0.05 \mathrm{~mL})$ of triethyl 4-phosphonocrotonate was added dropwise over $45 \mathrm{~min}$. The mixture was stirred in the cold for $45 \mathrm{~min}$ and $10.5 \mathrm{~g}$ (0.05 mol ) of 1-Tetradecanol was added dropwise with stirring over $1 \mathrm{~h}$. The reaction mixture was diluted to $1 \mathrm{~L}$ with water. The product was extracted by stirring with $\mathrm{Et}_{2} \mathrm{O}$ and ligroin. The combined extracts were dried $\left(\mathrm{Na}_{2} \mathrm{SO}_{4}\right)$ and evaporated: yield $7.6 \mathrm{~g}$.

Ethyl 2,4- octadecadienoate (7.5 g) was added to a solution of $3.75 \mathrm{~g}$ of potassium hydroxide in $50 \mathrm{ml}$ of methanol and the mixture was heated at gentle reflux for $2 \mathrm{~h}$. The mixture was cooled to room temperature, placed in separatory funnel, diluted with water, and washed by swirling with ligroin. The aqueous layer was acidified with hydrochloric acid, stirred for $0.5 \mathrm{~h}$. The solid was recrystallized from a small amount of ligroin. 


\section{DOEPC}

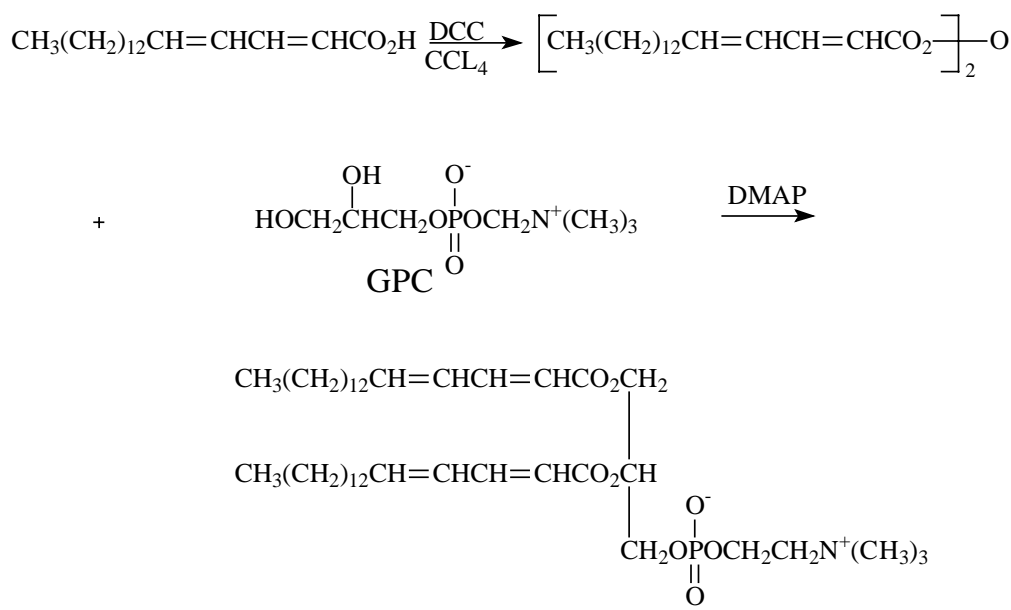

2,4-octadecadienoic acid (0.54 g, $2 \mathrm{mmol})$ was dissolved in $45 \mathrm{ml}$ of dry carbon tetrachloride. Dicyclohexylcarbodiimide $(0.22 \mathrm{~g}, 1 \mathrm{mmol})$ was added, and the reaction mixture was allowed to stand at room temperature for $24 \mathrm{~h}$ with occasional swirled. The precipitate was removed by filtration, and the filtrate was evaporated to dryness. The residue was taken up to a small amount of $\mathrm{Et}_{2} \mathrm{O}$ and filtered. The filtrate was chilled, and the precipitated solid was collected and dried. The solid was chromatographed on silica gel eluted with dichloromethane: yield $0.19 \mathrm{~g}$.

The GPC $(0.29 \mathrm{~g}, 0.66 \mathrm{mmol})$ was dried by repeated evaporation of dry benzene. The residue was suspended in $25 \mathrm{ml}$ of dry stabilize free, freshly distilled chloroform. The anhydride $(0.16 \mathrm{~g} 1.3 \mathrm{mmol})$ and 4-dimethylaminopyride $(0.86 \mathrm{~g}, 1.6 \mathrm{mmol})$ were added, and the reaction flask with dry nitrogen and tightly sealed, then was stirred at room temperature for $40 \mathrm{~h}$. The solvent was evaporated and was added $30 \mathrm{ml}$ of a 5:4:1 mixture of methanol, chloroform, and water. The solution was poured through a column of resin $(50 \mathrm{ml})$. The resin washed with $150 \mathrm{ml}$ of the same solvent. The combined effluents were evaporated, and the residue was chromatographed on silica gel eluted with a chloroform/methanol gradient, and the product was eluted with pure methanol: yield 0.06 g: NMR $\left(\mathrm{CDCl}_{3}\right) \delta 0.88\left(\mathrm{t}, 6 \mathrm{H},-\mathrm{CH}_{3}\right), 1.26($ br s, $40 \mathrm{H}$, $\left.-\left(\mathrm{CH}_{2}\right)_{20^{-}}\right), 1.41\left(\mathrm{~m}, 4 \mathrm{H},-\mathrm{CH}_{2^{-}}\right), 2.15\left(\mathrm{~s}, 4 \mathrm{H},-\mathrm{CH}_{2} \mathrm{C}=\mathrm{C}\right), 3.35\left(\mathrm{~s}, 9 \mathrm{H},\left(\mathrm{CH}_{3}\right)_{3} \mathrm{~N}^{+}\right)$ 3.60-4.50 (m, $\left.8 \mathrm{H},-\mathrm{CH}_{2} \mathrm{CH}_{2} \mathrm{OPO}_{3} \mathrm{CH}_{2-},-\mathrm{CH}_{2} \mathrm{O}-\right), 5.30$ (br s, $\left.1 \mathrm{H},-\mathrm{CHCO}_{2}\right)$, 
5.73-5.78 (t, $\left.2 \mathrm{H}, J=15 \mathrm{~Hz},-\mathrm{C}=\mathrm{CHCO}_{2}\right), 6.09-6.16\left(\mathrm{~m}, 4 \mathrm{H}, \mathrm{C}=\mathrm{CCH}_{2}-\right), 7.18-7.24(\mathrm{~m}$, $2 \mathrm{H}, \mathrm{CH}=\mathrm{CCO}_{2}$ ).

\section{REFERENCES}

Dorn, K.; Klingbiel, R. T.; Specht, D. P.; Tyminski, P. N.; Ringsdorf, H.; Obrien, D. F. J. Am. Chem. Soc. 1984, 106, 1627-1633. 